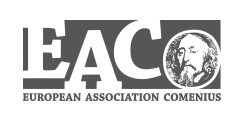

\title{
DeTERMinants OF THE SPATIAL Distribution OF Foreign EMPloyees on Different SKILl Job Positions: The CaSe of The Czech Republic
}

\author{
Soňa Schovánková ${ }^{1}$
}

\begin{abstract}
The aim of the paper is to discuss the spatial distribution of foreign employees in highlyskilled, skilled and unskilled job positions by using correlation and regression analyses. On the one hand, our results indicate that foreign employees, no matter what job position they work in, usually concentrate in districts where regional centers or eventually large industrial factories are located. The outcomes also indicate that these foreign employees are usually employed in areas where foreigners were also employed in previous years. On the other hand, there seem to be determinants of the spatial distribution of foreigners that differ by job positions. The spatial distribution of foreign employees in highly-skilled job positions seems to be primarily influenced by characteristics of the economic area, whereas the spatial pattern of foreign employees in skilled and unskilled job positions seem to be more determined by the characteristics of the labour market area.
\end{abstract}

\section{Keywords}

Statistics of Employment of Foreigners, Different Skill Job Positions, Spatial Distribution of Foreign Employees, Correlation and Regression Analyses, Czech Republic

\section{Introduction}

The role of migration in the contemporary world is significant and population movement is still gaining in importance. In this context, determinants influencing the spatial distribution of the foreign labour force are becoming a popular topic for researchers.

It is generally understood from previous studies ${ }^{2}$ that migrants concentrate in a limited number of regions depending on various specific economic, social, political and also

\footnotetext{
${ }^{1}$ Charles University in Prague, Faculty of Science, Geomigration Center, Albertov 6, 12000 Prague, Czech Republic and PricewaterhouseCoopers Česká republika, s. r. o., Hvězdova 1727/2, Prague, Czech Republic. E-mail: sona.schovankova@cz.pwc.com.

2 See e.g. Massey et al. (1993, 1998), Van Der Gaag, van Wissen (2001, 2002), Castles (2002), Tóth a Kincses (2010), Drbohlav (1995), Novotný et al. (2007).
} 
geographical determinants of the territory. In this respect, cities and metropolitan regions are usually more affected by international migration compared to rural areas or regions with socioeconomic difficulties. Moreover, it has been proved in several studies that the higher the number of previously arrived migrants in the location, the higher the subsequent immigration into the area.

The characteristics specified above may also be experienced in the Czech Republic, where the current spatial distribution of foreigners began to form in the 1990s. The outcomes repeatedly indicate an unequal regional distribution of migrants no matter what the purpose of their stay is, and show the level of dominance of the capital, Prague, and the significant importance of other large cities and their suburbs and also differences in concentration of migrants from certain countries in regions of the country. Moreover, the east-west gradient indicates that the number of migrants decreases from the west to the east, confirming the special dominant position of Prague and its suburbs ${ }^{3}$. As for labour migration, studies by Schovánková and Drbohlav (2013) and Schovánková (2013a, b) also showed three axes heading to the east, north and west of Prague and indicating a higher concentration of labour migrants in that areas.

The aim of this paper is to review the spatial structure of foreign employees by different skill levels and discuss their geographical and socioeconomic determinants of the distribution in districts of the Czech Republic. In the paper, we will analyse the data by applying correlation and regression analyses.

\section{Empirical framework}

The existing literature usually discusses either determinants of international migration flows between countries ${ }^{4}$ or determinants of the spatial distribution of international migrants in a concrete country ${ }^{5}$. In both of these approaches, we can identify various attitudes to the analyses of determinants of the spatial distribution of different groups of labour migrants. On the one hand, there are studies that focus on determinants of migration of the labour force without differentiation by the skill levels of migrants ${ }^{6}$. On the other hand, other studies focus on highly-skilled professionals, who are considered by some authors to be the "most valuable factors of production in the contemporary world economy" (Davis, Hart, 2007: 510). Movements of these individuals are usually studied in connection with temporary migration, relevant immigration policies that support this mobility, as well as corporate sector and transnational corporations ${ }^{7}$. In this context, it seems that significantly smaller attention is currently devoted to skilled or unskilled labour migrants, who usually work in a certain sector of the host country economy and are often connected with the

\footnotetext{
${ }^{3}$ See e.g. Drbohlav (1995), Drbohlav et al. (2010), Novotný et al. (2007), Čermák, Janská (2011).

${ }^{4}$ See e.g. Mayda (2007, 2010), Gibson, McKenzie (2012), Docquier et al. (2013), Chaloff, Lemaitre (2009), Bertoli et al. (2013).

${ }^{5}$ See e.g. Van Der Gaag and Van Wissen (2001), Tóth and Kinces (2010), Melegh et al. (2004), Gross and Schmitt (2006, 2012), Venturini, Villosio (2012), Lobodzinska (2011), Rovolis and Tragaki (2005).

${ }^{6}$ See e.g. Hanson (2013), Jennissen (2003, 2004), Massey (1993, 1998), Van Der Gaag and Van Wissen (2001), Tóth and Kinces (2010), Kostaki et al. (2013), Melegh et al. (2004).

${ }^{7}$ See also Koser, Salt (1997), Salt (1984, 1992), Khoo et al. (2007, 2011), Cerna (2010).
} 
remitting of saved money to the home country. These studies often focus on migration from certain countries, such as the Philippines, Mexico, Ukraine, etc., or on guestworkers ${ }^{8}$. The determinants of international migration can be divided into economic, social, cultural, geographical and political determinants. Examples of these determinants are: economic structure and labour market; composition of the population or stock of migrants in the territory; attitude of the population towards foreigners; migrants' knowledge of the mother tongue of the destination country; localisation of the destination to a border region or of the destination to the borders ${ }^{9}$; governmental and non-governmental organizations operating in the region and assisting immigrants in various life situations. There are an unlimited number of determinants and practically every paper can offer a different combination of various determinants. In this respect, authors often face difficulties with the availability of required data and their structure that are then often used in complicated econometric and mathematical models. ${ }^{10}$

Van Der Gaag and van Wissen (2001), for example, applied regression analysis on the determinants of the spatial distribution of migrants in Western Europe. They used economic, demographic as well as geographical variables to estimate the spatial pattern of international migrants in German regions. Their results indicated that, the more attractive a region is for foreigners, the lower the unemployment, while another outcome showed that, the higher the foreign population in the region, the higher the immigration, no matter what the level of urbanisation is in the region. Moreover, the higher the internal out-migration, the fewer foreign immigrants located in the region. Based on their results, the localisation of the region was not important. In another paper, Tóth and Kinces (2010) found that Budapest and Pest County seem to be the most attractive regions for foreigners and so are micro-regions for certain citizens in neighbourhoods based on the countries of origin of migrants, i.e. Romania, Ukraine and Serbia. Another result was obtained by Kostaki et al. (2009) who found that, in Greece, foreigners concentrate in economically-developed municipalities in metropolitan areas, in hinterland countryside and touristic coastal areas and islands.

A comparative study on the determinants of international labour migration in Finland, Hungary and Russia was worked out by Melegh et al. (2004). The results of the research indicate that the most attractive areas for international labour migrants seem to be regions of capital cities in all three countries, also some of the most urbanised areas in these countries. These economically successful regions are attractive not only for working foreign migrants but also for foreign investment and new companies. Moreover, the results of the study show that, the higher the overall economic development on a national and also regional level, the higher the international labour migration.

One of the few available papers on comparing the determinants of international migration to France by the different skill categories of occupations was carried out by Gross and

\footnotetext{
${ }^{8}$ See e.g. Azarnert (2012), Castles (2006), Jennissen (2003), Portes, Böröcz (1989), Drbohlav et al. (2010), Semyonov, Gorodzeisky (2005).

${ }^{9}$ For more on the border effects in the EU, see e.g. Huber, Pfaffermayer and Wolfmayr (2011).

${ }^{10}$ See e.g. Horvath (2012), Jennisen (2003, 2004), Willis (1975), Wermuth and Wermuth (1975), Mayda (2007), Gächter, Schwazer and Theurl (2012), Novotný et al. (2007).
} 
Schmitt $(2006,2012)$. Their results indicate that low-skill migration is driven by standard push and pull migration factors such as income, unemployment rate, cultural networking, population, etc., whereas only financial incentives seem to matter for highly-skilled migration. Study of the international migration of different skill level individuals between the two countries was carried out by Docquier et al. (2013). These authors used a large set of bilateral data for a group of countries trying to estimate the demographic, economic, sociological and political dererminats of international migration in 1990 and 2000. Their outcomes indicate that common borders between the two countries were important for low-skilled migrants both in 1990 and 2000. The importance of immigration from the former colony country seemed to play important role for highly-skilled as well as skilled migrants more in 2000 than in 1990. The level of the gross domestic product seemed to play an important role in 1990, while it was not that important in 2000.

Czech literature offers only a few studies on the determinants of the spatial distribution of migrants. These studies work with officially published data on foreign migrants staying in the Czech Republic without differentiation by the various purposes for their stay (e.g. employment, business, family reunion, study). The results of the analysis carried out by Novotný et al. (2007) indicate that horizontal geographical position is statistically important in connection with the distribution of international migrants; surprisingly, unemployment and the economic structure of districts does not seem to be important for them. Čermák and Janská (2011) focused in their paper on in-migration and international migration of foreign migrants in districts of the Czech Republic and its determinants. Their results indicate that the unemployment rate and average wage in the district are important for in-migration as well as the international migration of foreigners. Prague is a dominant destination for both in-migration and international migration of foreigners. Moreover, their outcomes showed a stronger influence of economic factors on migration to the most attractive districts. On the other hand, social and ethnic relations seem to be important for migration communities in areas with lower net in-migration.

Based on the introduction and the theoretical framework introduced above, we identified the following questions that we will try to answer in the paper: 1) What is the structure of foreign employees in the Czech Republic in 2011 by different skill levels? 2) What are the most important determinants associated with the spatial distributional pattern of foreign employees on different skill levels in the Czech Republic in 2011.

The remainder of the article is structured as follows. In Section 3, we introduce statistical data that will be used in the analysis. Section 4 examines the spatial distribution of foreign employees by different skill job positions. Sections 5 and 6 are devoted to the correlation and multilinear regression analyses where empirical results on determinants of the spatial distribution of foreign employees in different skill job positions are discussed. Section 7 presents the conclusion, wherein the most important results are summed up.

\section{Statistical data and their sources}

Statistics on foreigners employed in the Czech Republic is available from the Ministry of Labour and Social Affairs ("MLSA") by the type of employee registration with the 
authority that is carried out in the district of the individidual's place of work and also the classification of job positions, citizenship of foreigners as well as the district (LAU $1^{11}$ ). In our study, we will gradually touch on all of these characteristics. Apart from data on employed foreigners registered with the authority, we also used the statistics of the Czech Statistical Office ("CSO"), which collects various socioeconomic data provided by other authorities, including MLSA, the Ministry of the Interior ("MI"), the Ministry of Industry and Trade ("MIT"), the Czech National Bank ("CNB"), etc. CSO data are available monthly, or on a quarterly or annual basis by districts. In our analysis, we worked with the statistical data between 2008 and 2011.

Before we proceed to the empirical outcomes of the study, it is necessary to clarify what is behind the statistical data on foreign employees in the Czech Republic that we used.

Czech authorities consider foreign to be every individual who is not a citizen of the Czech Republic, i.e. any person holding other than a Czech passport ${ }^{12}$. Moreover, Czech legislation differentiates between $\mathrm{EEA}^{13}$ and Swiss foreigners and foreigners from socalled third countries ${ }^{14}$. These groups of foreigners differ in the legislative obligations that have to be met prior to when employment can be commenced.

We can currently identify three main groups of indicators ${ }^{15}$ of the employment of foreigners. In the following paragraph, we will characterise types of employee registration with the respective authority and the indicators that we applied in our study $\left.{ }^{16}: 1\right)$ Registration of EEA citizens - EEA workers may enter the Czech labour market freely and can be hired under the same conditions as Czech citizens. There is no obligation to test the local labour market prior to employing these workers. When the individual is hired, the employer is obliged to register the individual with the Labour Office; 2) Registration of third-country citizens - there are two possible indicators that differ by the conditions to be met in the event that these individuals want to enter the Czech labour market. The first indicator is applicable to third-country citizens who meet the condition of being exempted from the need for a work permit ${ }^{17}$. These employees are entitled to enter the labour market

\footnotetext{
${ }^{11}$ LAU is the abbreviated Local Administrative Units that are territorial units that replaced NUTS 4 in 2008. LAU 1 corresponds with the level of districts ("okresy") and LAU 2 corresponds with municipalities. It was created for the purpose of the statistics of the regions and stands apart from the NUTS system, LAU does not have legislative support. The LAU system does not have a legislative background (CSO 2013a).

${ }^{12}$ Act No. 326/1999 Coll., on Stay of Foreigners on the territory of the Czech Republic.

${ }^{13}$ EEA is the abbreviation of the European Economic Area that comprises EU countries, Norway, Iceland and Lichtenstein. Citizens of Switzerland can enter the Czech labour market under the same conditions as EEA citizens. In the text below, we will abbreviate "EEA and Switzerland" as "EEA".

${ }^{14}$ Foreigners from third countries are citizens of other countries than the Czech Republic, EEA countries and Switzerland.

${ }^{15}$ From the methodological point of view, also an alternative approach of mulit-criteria indices could be used, as described in e.g. Kotlán and Machová (2012).

16 Third-country citizens may be also employed based on the Green Card or Blue Card. In 2011, only a few dozen of these permits were valid. Due to the very low number of these permits, we will not include them in our study.

17 The list of exemptions from the need for a work permit is set in the Act on Employment and includes family members of Czech or EEA citizens, holders of permanent residence permits and their family members, shortterm assignments up to 30 days of work and other assignments from any EU country, students and graduates of secondary and tertiary education, academic workers and researchers, etc.
} 
under the same conditions as EEA foreigners, i.e. no test of the labour market is required, employer is obliged to carry out the registration with the labour office; 3) Issued work permits - another indicator of the employment of foreigners from third countries are issued work permits. In general, issuance of a work permit is administratively demanding and includes both the testing of the labour market and also presenting a set of supporting documents to the labour office proving that there is no Czech or EEA candidate who would meet the employers' requirements for the position. Statistical data are available for issued first work permits and also renewed work permits. Empirical analyses on statistical data indicates that the available statistics of first issued work permits ${ }^{18}$ is overestimated (Schovánková, 2013a), and therefore we will use the indicator of "renewed work permits" in our study, which shows the number of third-country workers who should in fact work in the Czech Republic and who have proved via an existing visa or residence permit that they arrived in the Czech Republic (even though they may not be temporarily available in the country).

Statistical data specified in the previous paragraph are available by types of job positions coming out from the classification of job positions ("CZ-ISCO classification") ${ }^{19}$. This classification categorizes work positions into so called "classes" and "sub-classes" reflecting the type of work performed. In this respect, individuals are expected to carry out working activities in a work position by virtue of skills formed by various factors, including their capabilities, the character of the work, their level of education reached and the importance of previous work experience ${ }^{20}$. Based on the character of the classification and its stress on skills and capabilities, we were able to categorize classes into three skill group categories (see Table 1): 1) Highly-skilled job positions, comprising classes 1 and 2 (for clarification, see Schovánková 2013b); 2) Skilled job positions, covering classes $3-8 ; 3)$ Unskilled job positions are covered by class 9.

\footnotetext{
18 The statistics on so-called "first work permits" is considered to be overestimated. The reason for this is the fact that the first work permit is usually obtained by an individual who does not yet reside in the Czech Republic and the work permit is the key supporting document for the visa or residence permit application that the individual needs to obtain prior to their arrival in the Czech Republic and commencement of the employment activities. According to Schovánková (2013a), between 2008 and 2011, there arrived in the Czech Republic 2-10 times fewer foreigners from Ukraine, Vietnam and Mongolia than held a visa or residence permit for the purposes of employment purpose compared to the number of issued first work permits.

${ }^{19}$ CZ-ISCO classification is the statistical classification of job positions created by Czech authorities and arises from standardised International Standard Classification of Occupations (ISCO-08) of the International Labour Organisation (ILO). CZ-ISCO classification replaced classification of employment (KZAM-R) in 2012. (CSO 2012).

${ }^{20}$ CSO (2012), ISPV (2012), Schovánková (2013b).
} 


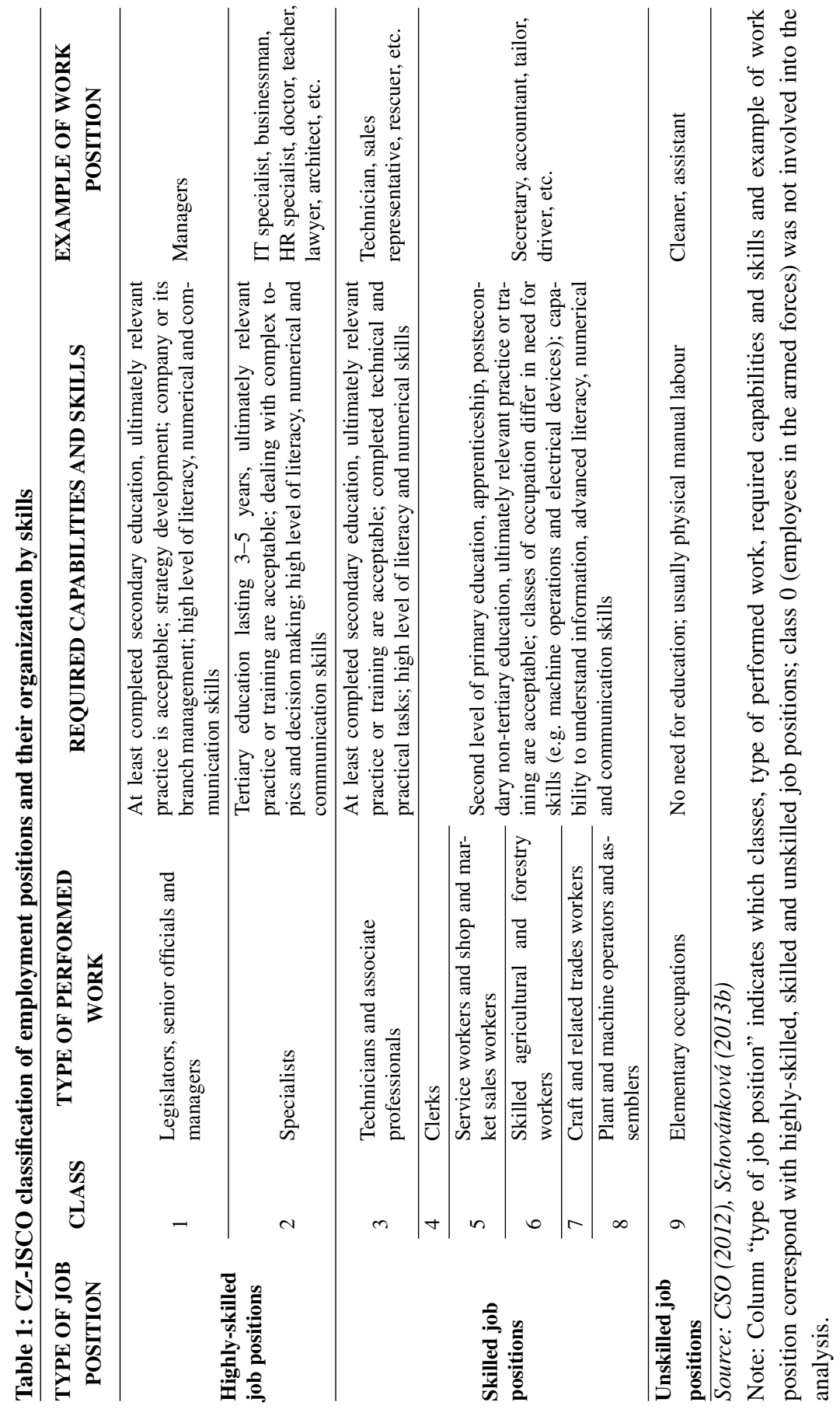




\section{Spatial distribution of foreign employees by different skill levels}

The total number of foreign employees registered at the labour office (first work permits were excluded) was about 200,000 in 2011. Most employees originated in Slovakia, Ukraine and Poland. When we take a closer look at the statistics of job positions of employed foreigners by their skill requirements (see Table 2), we can see that skilled job positions accounted for slightly more than $60 \%$ of all foreign employees registered at labour offices, followed by registered foreign employees in unskilled job positions (23\%) and highly-skilled positions (about 16\%).

As for different indicators of registrations with the labour office, the most numerous are registrations of EEA foreigners, which make up three-quarters of the total number of employees registered with the authority. When we take into consideration job positions by skill requirements, we can see that registrations of EEA employees in skilled job positions made up almost $50 \%$ of all registered employed foreigners. Another interesting finding related to renewed work permits. The results indicate that the share of foreign employees in unskilled job positions was slightly higher compared with foreign employees in skilled job positions. Moreover, the indicator of renewed work permits was very low in the case of employed foreigners in highly-skilled job positions, which was in fact the lowest measured value by different skill job positions and registration with the labour office. Moreover, our data indicate that skilled job positions are more often occupied by third-country citizens registered with the labour office than by foreigners in unskilled job positions.

As for the structure of the most numerous groups of employed foreigners by citizenship, we can see that Bulgarians do not often work in highly-skilled job positions, being more likely to be found in skilled and unskilled ones. A similar situation persists for Moldovans and Uzbeks, who work primarily in unskilled positions. The results also indicate that Moldovans and Uzbeks are two of the three largest groups of renewed work permit holders. In this respect, when we take into account the fact that registrations of thirdcountry citizens with the labour office are usually carried out if that individual obtains a permanent residence permit, this does not yet seem to be the case for Moldovans and Uzbeks. Despite still low numbers, our results may indicate the emergence of new source countries of employment migration for the Czech Republic - Moldova and Uzbekistan. 


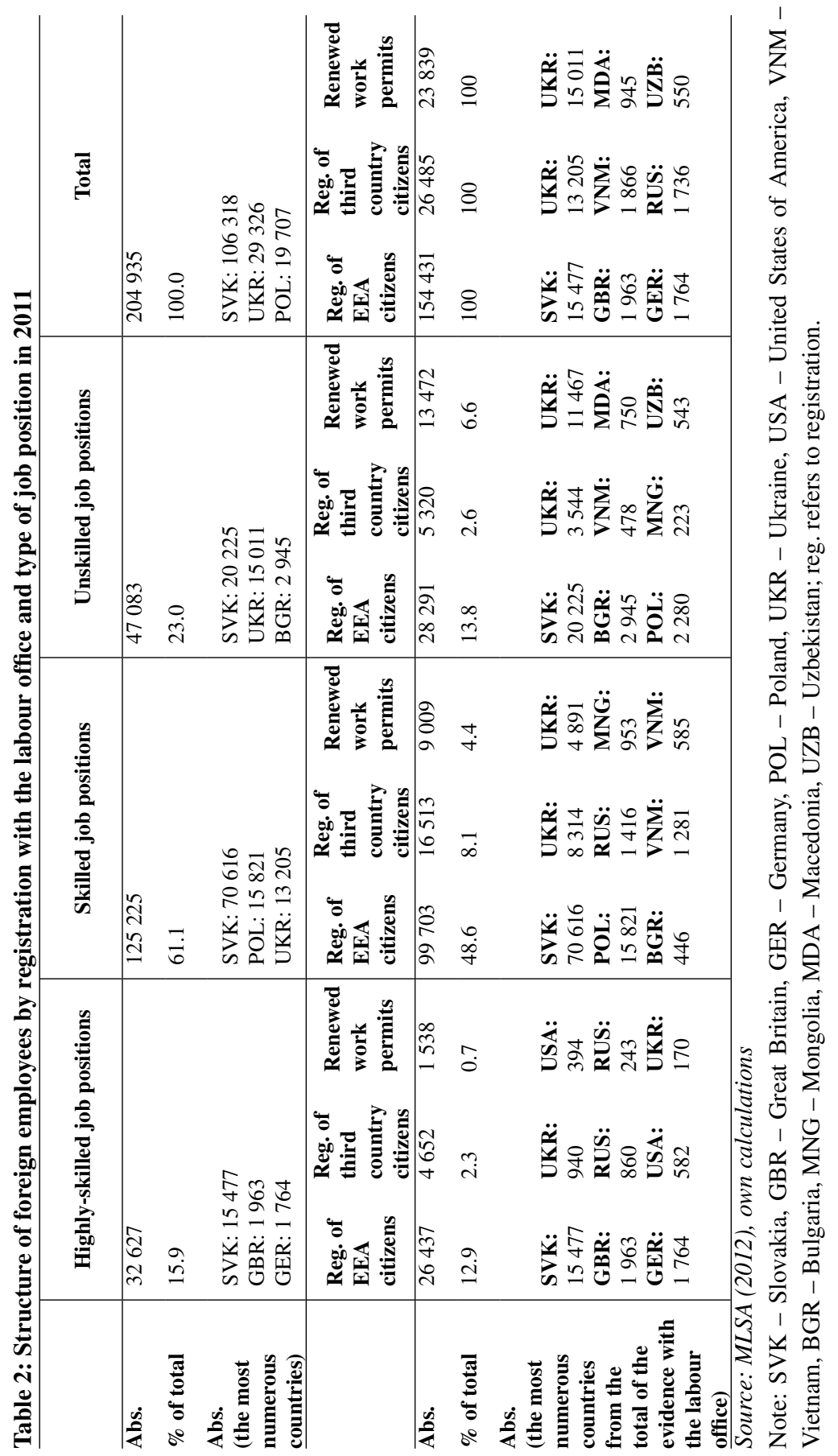


The spatial distribution of foreigners employed in highly-skilled job positions (Figure 1) was characterised by the highest concentration in the metropolitan areas of Prague and Ostrava $^{21}$ as well as in the Brno district. A higher concentration of these employees was also found in other areas where regional centers are located (the only exception in this respect was the Jihlava district) and in the district of Mladá Boleslav, where the Škoda Auto company is located. A higher concentration of foreigners employed in highly-skilled job positions was also found in districts bordering Slovakia. On the contrary, the largest continuous area of the lowest concentration of foreign employees in highly-skilled job positions was in the rural districts ${ }^{22}$ south-west of Prague bordering Bavaria and including the Plzeň-south and Plzeň-north districts.

In the case of foreign employees in skilled job positions (Figure 2), we can see a more intensive concentration in the districts of Bohemia compared with foreign employees in highly-skilled job positions. When we take a closer look, we can identify the highest concentration of foreign employees not only in the Prague and Ostrava metropolitan areas, but also in Brno, Plzeň and Liberec districts and other districts where regional cities are located (except the districts of Ústí nad Labem and Jihlava). A higher concentration of these employees was also found in the districts located on the axis north of Prague, i.e. the Mladá Boleslav district, where the Škoda Auto company is located, to the Liberec district. Another, however, not that significant axis headed east of Prague to districts on the borders with Poland.

Foreign employees in unskilled job positions (Figure 3 ) were more concentrated in districts of Bohemia, compared to the districts of Moravia and Silesia in 2011. The highest number of these employees was in Prague, Ostrava and Brno ${ }^{23}$ metropolitan areas and also in Plzeň. A significant number of foreign employees in unskilled job positions in the records of the labour office was also found in the districts of Mladá Boleslav, Kolín and Pardubice, which is probably connected with the presence of large factories such as Škoda Auto, TPCA and Foxconn.

\footnotetext{
${ }^{21}$ We consider the Prague metropolitan area to be composed of the regions of Prague, Prague-east and Praguewest. The Ostrava metropolitan area comprises the regions of Ostrava, Karvina and Frýdek Místek. (see e.g. Hampl, 2001, 2005).

${ }^{22}$ See Hampl $(2001,2005)$.

${ }^{23}$ The Brno metropolitan area covers Brno and Brno-rural area regions. The Plzeň metropolitan area is formed by the Plzeň, Plzeň-north and Plzeň-south regions.
} 
Figure 1: Spatial distribution of foreign employees in highly-skilled job positions in 2011

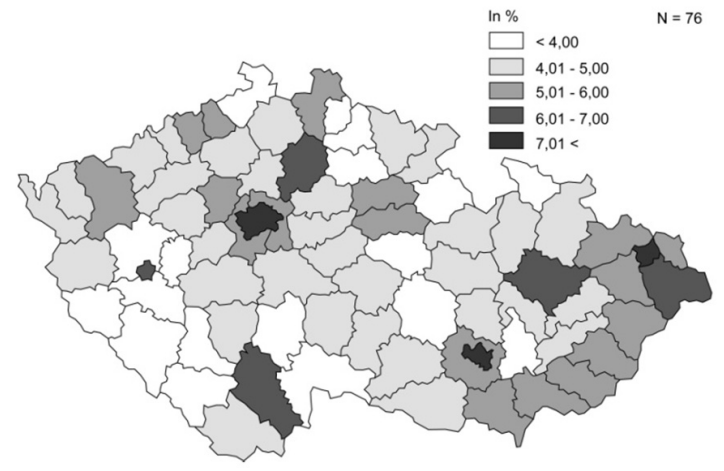

Source: MLSA (2012)

Figure 2: Spatial distribution of foreign employees in skilled job positions in 2011

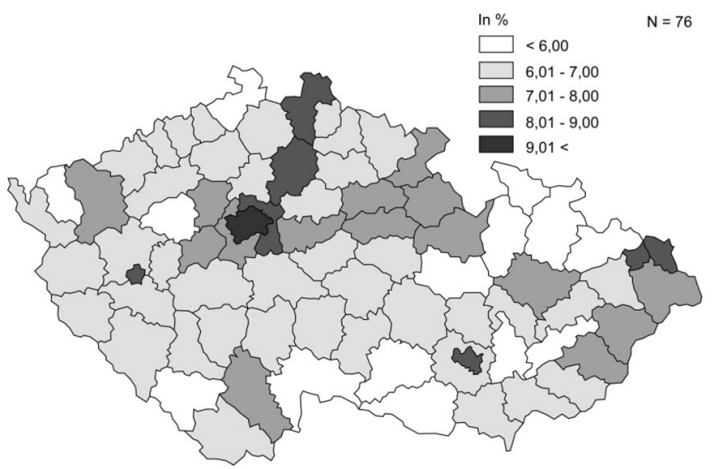

Source: MLSA (2012)

Figure 3: Spatial distribution of foreign employees in unskilled job positions in 2011

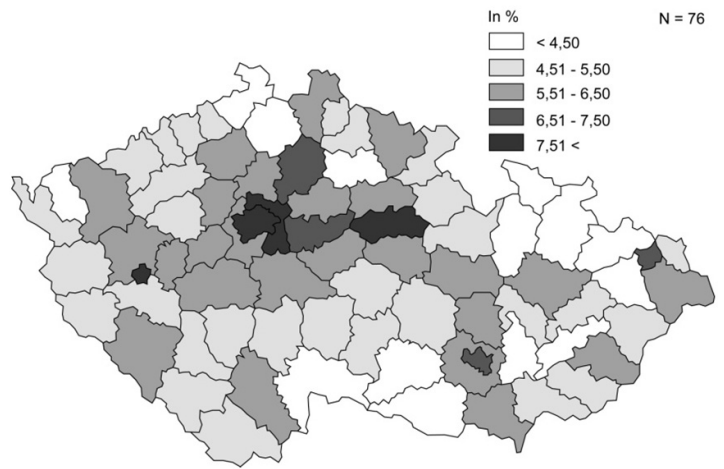

Source: MLSA (2012) 


\section{Correlation analysis}

In this section we use a Pearson coefficient of correlation to measure the strongest mutual dependency between 22 variables of geographical and socioeconomic characteristics covering five areas (geographical position, migration and mobility, demography and social characteristics, labour market, economic characteristics) ${ }^{24}$ and variables of foreigners employed in highly-skilled, skilled and unskilled job positions by LAU 1 districts ${ }^{25}$. Based on the outcomes of the correlation analysis, we will select relevant variables for the regression analysis that will be specified in Section 6. In the correlation analysis, we will exclude Prague due to its dominant position in the Czech settlement system and also its dominant position in the employment of foreigners ${ }^{26}$.

Absolute numbers of foreign employees in highly-skilled, skilled and unskilled job positions do not consider their different distribution in the territory, and therefore we transformed the data and used a natural logarithm $(\ln )$ so that our interpretations of the results are more relevant. The results of the correlation analysis are available in Table 3.

\footnotetext{
${ }^{24}$ The decision to use these variables in this analysis depends not only on the availability of data but also on our opinion that these variables may clarify the spatial differentiation patterns of foreigners employed in highly-skilled, skilled and unskilled job positions. (see also Novotný et al. 2007, Van Der Gaag, Van Wissen 2001, Rovolis, Tragaki 2005, Čermák, Janská 2011, Melegh et al. 2004, Horvath 2012, Gächter, Schwazer and Theurl 2012).

${ }^{25}$ See footnote no. 10 for clarification.

${ }^{26}$ See Figures 1-3 and also e.g. Čermák, Janská (2011), Schováková, Drbohlav (2013), Hampl (2001, 2005), Blažek, Csank (2007), Blažek, Netrdová (2009).
} 
DOI: 10.2478/danb-2013-0006

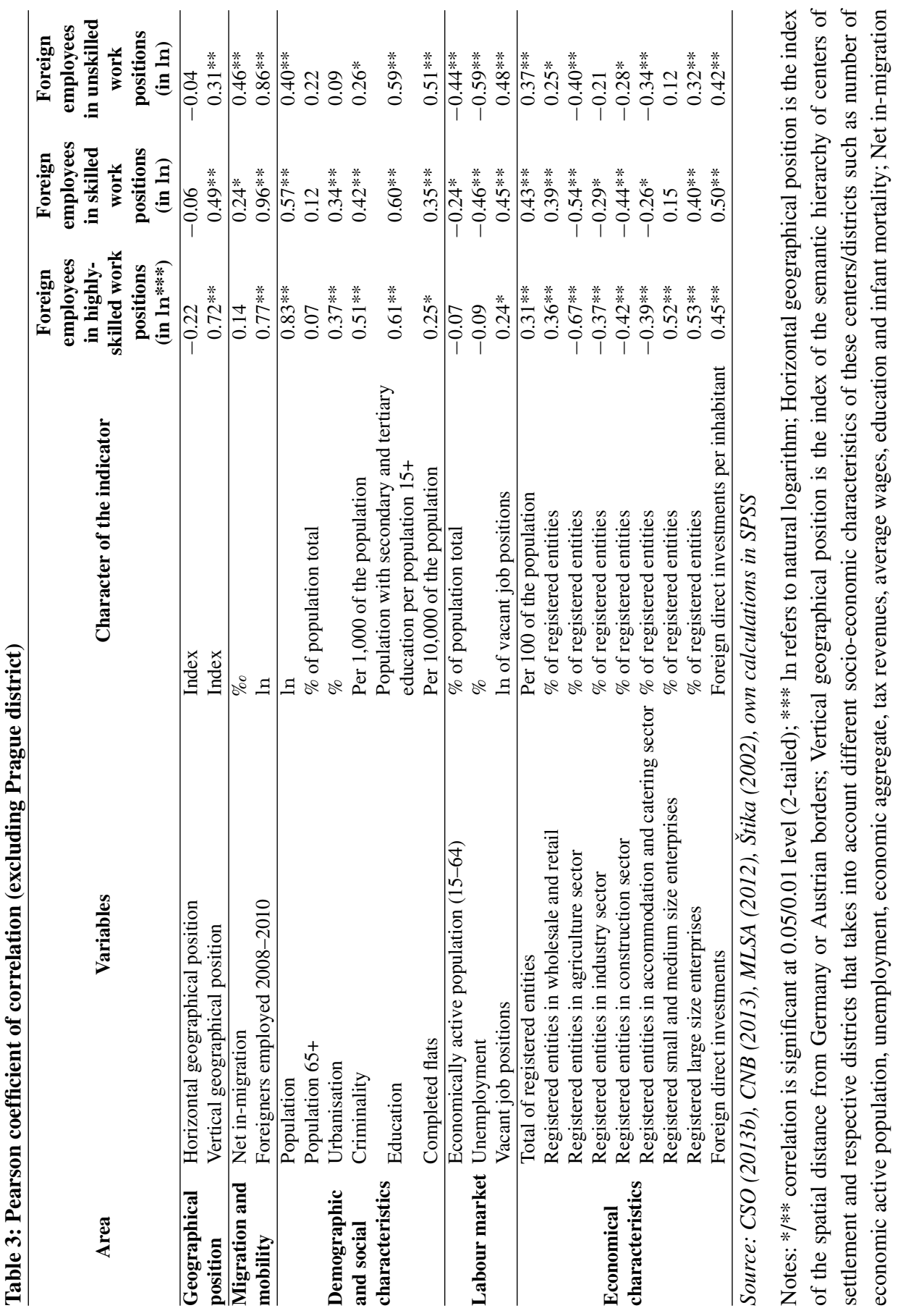




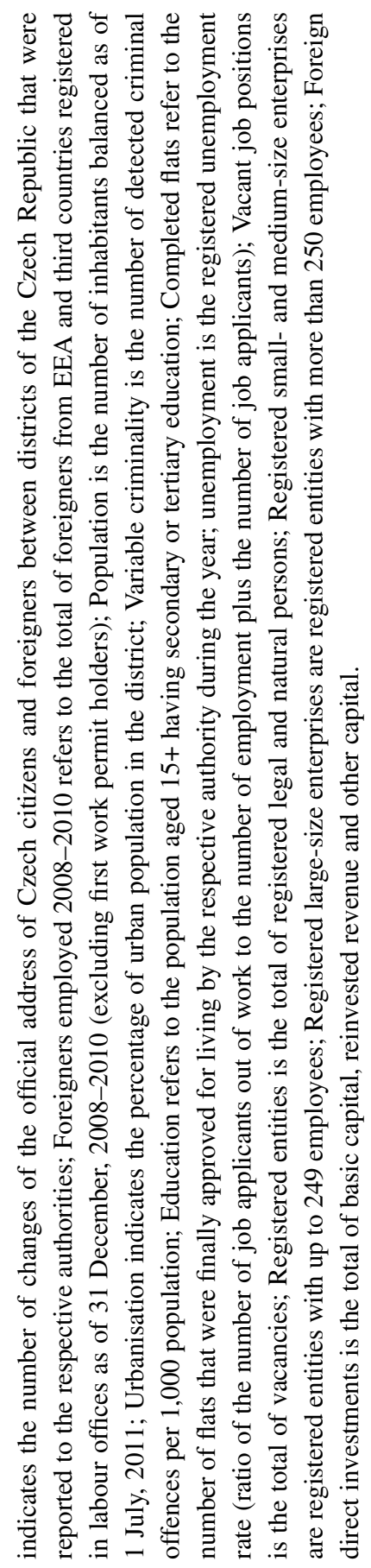


Differentiation of districts by their geographical position was measured by using two variables. The first was the variable of the horizontal geographical position that indicates the distance of the largest city of the district from German or Austrian borders; another variable was the vertical geographical position reflecting the position of the district in the hierarchy of settlement (see Table 3). While the correlation between horizontal geographical position and foreign employees in highly-skilled job positions indicates a negative and weak, but still statistically significant relation, the relation between horizontal geographical position and foreign employees in skilled and unskilled job positions is considered statistically unimportant. As for the relation between vertical geographical position and foreign employees in highly-skilled, skilled and unskilled job positions, the correlation shows a significant positive relation that is highest in the case of foreign employees in highly-skilled job positions. This result indicates that the position of the district in the hierarchy of settlement is important primarily for foreign employees in highly-skilled job positions who concentrate more in large regional cities (see also Figure 1) and less important for foreign employees in skilled and unskilled job positions, who are more widely dispersed in districts of the Czech Republic (see also Figure 2 and 3) compared to foreign employees in highly-skilled job positions.

Other variables related to migration and mobility (see Table 3 ). We used two variables - net immigration and foreigners employed between 2008 and 2010. ${ }^{27}$ The results indicate a low positive relation for foreign employees in highly-skilled job positions and a significantly stronger positive relation with foreign employees in skilled and unskilled job positions. We also expected a positive relation between foreigners employed between 2008 and 2010 and foreign employees in highly-skilled, skilled as well as unskilled job positions. This assumption was proved by the results of the correlation showing a very strong relation with the variables of foreign employees in highly-skilled, skilled and unskilled job positions. Demography and social areas include six different variables (see Table 3 and its notes). The first of these is the population size in the district, which showed a very strong positive relation with the variables of foreigners employed in highly-skilled (the correlation was 0.83 ) and skilled job positions (correlation was 0.57) and a strong relation with foreign employees in unskilled (correlation was 0.40) job positions. Another variable of the population aged $65+$ indicates a positive, although very weak relation with foreign employees in skilled and unskilled job positions and an unimportant relation with foreign employees in highly-skilled job positions. On the contrary, a relatively strong positive correlation was found between the variable of urbanisation and foreigners employed in highly-skilled and skilled job positions. An unimportant relation was measured in the case of the variable of urbanisation and foreign employees in unskilled job positions. The variable of criminality proved a relatively strong positive correlation with foreign employees in highly-skilled and skilled job position and a weaker, although statistically important positive relation with foreigner employees in unskilled job positions. The variable of education indicates a rather strong relation with foreign employees in highly-skilled, skilled as well as unskilled job positions. The last variable in this area - completed flats - proves a positive

${ }^{27}$ See also Van Der Gaag and Van Wissen (2001), Novotný et al. (2007). 
and relatively strong relation with foreign employees in highly-skilled and skilled job positions and a strong relation with foreign employees in unskilled job positions.

The fourth group of variables are the characteristics of the labour market. In this group we used indicators of economic active population, the unemployment rate and vacant job positions (see Table 3). Our outcomes indicate that the variables bear different information in relation to foreign employees in highly-skilled, skilled and unskilled job positions. Firstly, we found a statistically unimportant relation between the economically active population and foreign employees in highly-skilled job positions, a weak negative relation with foreign employees in skilled job positions and a stronger negative relation with foreign employees in unskilled job positions. As for the variable of unemployment, we experienced a statistically unimportant relation with foreign employees in highly-skilled job positions, which indicates that the distribution of these employees is not related to the unemployment situation of the district. In the case of the relation between the unemployment rate and foreign employees in highly-skilled and unskilled job positions, we measured a negative and relatively strong correlation. As for the relation to vacant job positions, we found a significantly positive relation with foreign employees in highly-skilled, skilled as well as unskilled job positions.

The last area of variables related to economic characteristics. In this respect, we used the largest range of variables (see Table 3). The variables of the total of registered entities and registered entities in the wholesale and retail sector indicate a positive and relatively strong relation with foreign employees in highly-skilled, skilled as well as unskilled job positions. Relations between the variables of entities in sectors of agriculture, industry, construction and accommodation and catering and foreign employees in highly-skilled, skilled and unskilled job positions was measured as a negative statistically important correlation of -0.21 to -0.67 . The variables of registered small and medium enterprises and registered large enterprises show a strong positive relation with foreign employees in highly-skilled job positions. Nevertheless, in the case of foreign employees in skilled and unskilled job positions, we can see a weaker, although significant positive correlation with registered small- and medium-sized enterprises and a relatively strong positive relation with registered large-sized enterprises. Foreign direct investments are the last variable in the area of economic characteristics. The correlation between this variable and foreign employees in highly-skilled, skilled and unskilled job positions shows a strong positive relation.

The main outcomes of the correlation analyses indicate that there is a very strong positive relation between the variables of foreigners employed from 2008-2010 and foreign employees in highly-skilled, skilled as well as unskilled job positions, which shows that foreign employees are usually employed in districts as foreign employees who came in previous years. A very strong relation is also found between foreign employees in highly-skilled job positions and a vertical geographical position. This result indicates that the semantic hierarchy of settlement is an important factor in the distribution of foreign employees - the higher the semantic position of the district in the hierarchy of settlement, the more foreign employees in highly-skilled job positions are employed in the district. Also interesting is the statistically unimportant relation between unemployment 
and foreign employees in highly-skilled job positions, which indicates that the spatial distribution of foreign employees in highly-skilled job positions is not influenced by the unemployment in the district. Nevertheless, the relation of foreign employees in skilled and unskilled job positions and unemployment was negative and statistically important.

Last but not least, the common feature of the correlation analysis of determinants of the spatial differentiation of foreign employees in highly-skilled, skilled and unskilled job position is the same effect (positive or negative) between variables of geographical and socioeconomic areas and foreign employees in highly-skilled, skilled and unskilled job positions.

\section{Multilinear regression analysis}

The correlation analysis (see Section 5) served as a kind of pre-analysis for the multilinear regression analysis that enables us to test the importance and the character of the relation between determinants associated with the distribution of foreign employees in highlyskilled, skilled and unskilled job positions. It helps us to indicate the relations among a single criterion measure and one or more predictor measures. Moreover, like correlation, it indicates whether two variables move together and also estimates how (Willis 1975: 42).

The dependent variables that we used in our regression analysis were variables of foreign employees in highly-skilled, skilled and unskilled job positions. As for the independent variables, we applied the relevant geographical and socioeconomical characteristics introduced in the correlation analysis above (Section 5), taking into account the assumptions of the linear regression analysis ${ }^{28}$.

We worked out two models for each of the dependent variables (Models 1 to 6). In the first model, (i.e. Models 1, 3, 5), we applied only those independent variables which, based on the correlation analysis in Section 5, seemed to have a strong relation with the dependent variables. In the other model, we also applied those independent variables that correlated with the dependent variables; however, the relation was not so strong (see Models 2, 4, 6). The regression analysis was carried out for LAU $1^{29}$ districts excluding the district of Prague $^{30}$. Our findings are available in Table 4.

The results of the regression analysis for foreign employees in highly-skilled job positions indicate that their spatial distribution may be influenced by the variables of registered small- and medium-sized enterprises, criminality and foreign direct investments (see Model 1). However, when we also include other variables in this model (see Model 2), we can see that the importance of the variable foreign direct investments decreased in importance; however, the total registered economic entities may play an important explanatory role. Moreover, the variables of net in-migration, vacant job positions and

\footnotetext{
28 We selected relevant variables based on statistical relations between every two variables. In this respect, we tested more models to eliminate those variables which would not help to explain the variability, i.e. did not meet the conditions of the multilinear regression analysis primarily due to multicollinearity and data normal distribution (see e.g. Novotný et al. 2007, Spurná 2008, Nosek 2010).

29 See footnote no. 10 for clarification.

${ }^{30}$ See Section 5 for clarification of the exclusion of the Prague district.
} 
also horizontal geographical position do not seem to be important determinants in this model. The spatial distribution of foreign employees in skilled job positions seems to be determined primarily by unemployment, the vertical geographical position, criminality and vacant job positions (see Model 3 and Model 4). Surprisingly, the total of registered entities and foreign direct investments are not statistically significant determinants in either of the models. The regression analysis carried out for the dependent variable of foreigners employed in unskilled job positions indicates that vacant job positions, economic active population and unemployment seem to be important determinants (see Model 5). In the extended model (Model 6), which also includes other relevant variables, we can see that unemployment, vacant job positions, net in-migration, as well as vertical geographical position, seem to be important determinants; however, the variable of the economic active population loses its importance.

Both the correlation and regression analysis showed that the determinants of the spatial distribution of employed foreigners in different skill job positions vary by the different skill levels of the positions. 
DOI: 10.2478/danb-2013-0006

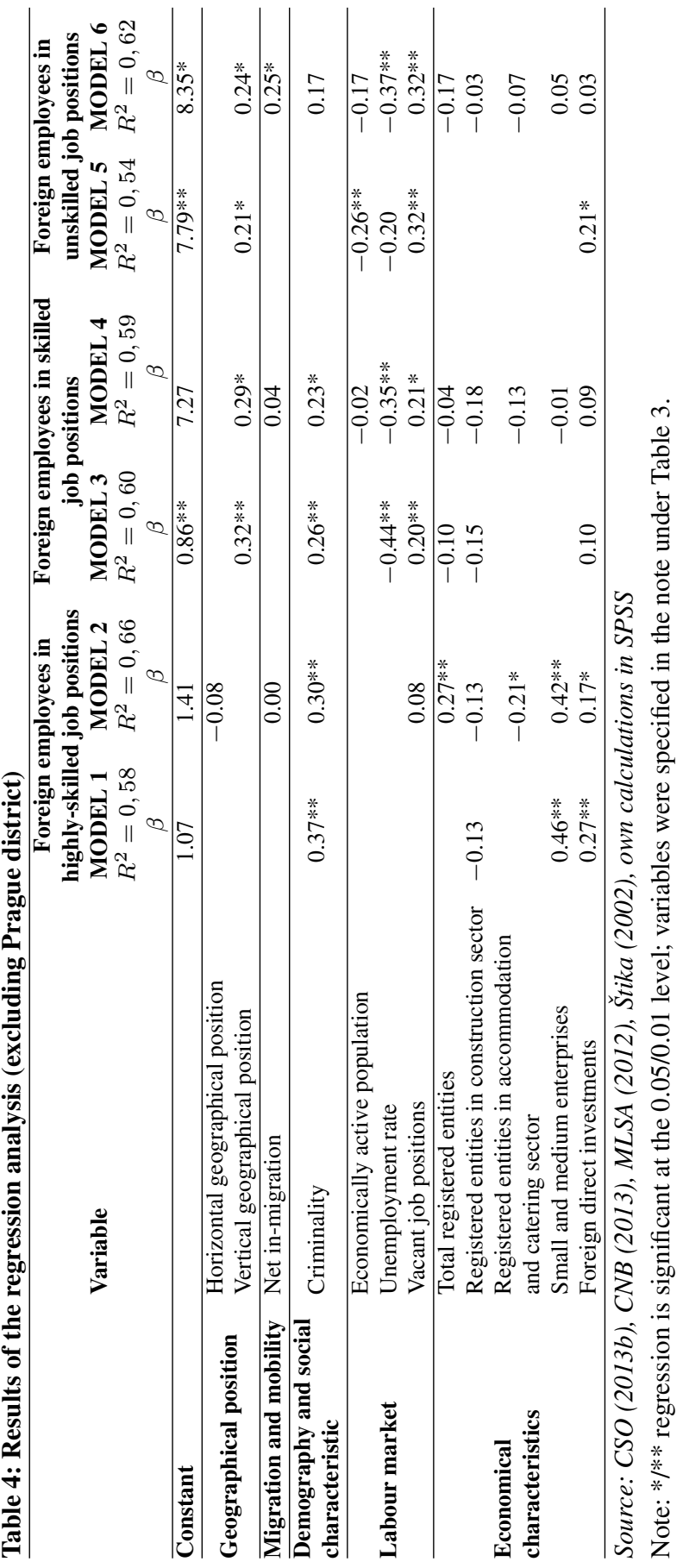




\section{Conclusion}

Our paper is a contribution to the scarce literature on empirical and quantitative analyses on the employment of foreigners by different levels of skill in job positions in the Czech Republic. The first aim of this paper was to study the structure of foreign employees in highly-skilled, skilled and unskilled job positions in districts of the Czech Republic. Our results indicate that about $60 \%$ of foreigners were employed in skilled job positions, whereas foreigners employed in unskilled job positions were about one quarter of the total and in highly-skilled job positions only about $16 \%$ were foreign. These results indicate that foreign employees in highly-skilled job positions are not often employed in the Czech Republic, which may be caused by the fact that they have little interest in being employed in the Czech Republic or that the Czech business environment has little interest in employing them, or ultimately by the competition existing between Czech, EEA and third-country foreign employees. However, the Czech Republic seems to be interesting for foreign employees in skilled job positions. When we compare foreign employees by citizenship, we can see that about $50 \%$ of them (no matter the job position) come from Slovakia, while another large group are Ukrainians and Polish citizens. As for the spatial distribution, foreigners employed in highly-skilled, skilled and unskilled job positions concentrate primarily in the largest cities of the Prague and Ostrava metropolitan areas and in the Brno and Plzen districts. This finding also corresponds with the findings of Van Der Gaag and Van Wissen (2001), who studied German regions, as well as Melegh et al. (2004), who studied regions in Finland, Hungary and Russia. Foreign employees in highly-skilled, skilled and unskilled job positions are also often employed in the districts of Mladá Boleslav, Pardubice and Kolín, where large factories of Škoda Auto, Foxconn and TPCA are located. The west-east gradient of the spatial distribution of employed foreigners (Bohemia versus Moravia and Silesia) can be found in the case of foreign employees in skilled and unskilled job positions; however, this was not observed in the case of foreign employees in highly-skilled job positions.

Another aim of the paper was to identify the determinants of the spatial distribution of foreign employees in highly-skilled, skilled and unskilled job positions. The study was carried out by applying correlation and multiregression analyses. The independent variables that we used covered five areas - geographical position, migration and mobility, demography and social characteristics, labour market and economical characteristics. The selection of variables was limited by their availability by districts (e.g. we were not able to use the variable of wages, as data for the variable were not available by districts (LAU 1) for 2011, only by NUTS 0, NUTS 1 and NUTS 2). Our analysis was carried out for districts of the Czech Republic excluding Prague, as that has a dominant position in the system of the semantic hierarchy of settlement. We identified two variables that may significantly impact the spatial distribution of foreign employees in highly-skilled, skilled as well as unskilled job positions. The first is the variable of foreigners employed in districts 2008-2010. The outcome indicates the crucial importance of migrant networks for the localisation of employed foreigners no matter what their job position is and also a possible stable economic basis that is being intensively used by foreign employees. The other variable is the vertical geographical position, which indicates that the position of 
the district in the semantic hierarchy of settlement plays an important role in connection with the distribution of foreign employees. Moreover, other results indicated that there were also determinants of the spatial distribution of foreigner employees that differed by skill positions, which was also examined in the papers of Gross and Schmitt $(2006,2012)$. In this respect, the spatial distribution of foreigners in highly-skilled job positions seems to be significantly influenced by determinants from the area of economic characteristics. As for foreign employees in skilled and also unskilled job positions, there seemed to be important variables from the area of the labour market. An interesting outcome was seen in the case of the variable of unemployment (a variable from the labour market area) that was found to be an unimportant variable in the spatial distribution of foreign employees in highly-skilled job positions; this, however, seems to be an important determinant of the spatial distribution of foreign employees in skilled and unskilled job positions, which also corresponds with the results of Gross and Schmitt (2006).

In connection with this paper, it would be interesting to accompany our quantitative analysis with a qualitative analysis that could confirm the results of the study and also indicate other spatial determinants of the distribution of employed foreigners. Moreover, it would also be interesting to study the determinants of the spatial distribution of employed foreigners in more detail by their citizenships or the differentiation between EEA/EU and third-country citizens. Another interesting topic could be the comparison of determinants of labour migration between the Czech Republic and Central European countries or between the Czech Republic and discrete immigration source countries.

\section{Acknowledgement}

The contribution was worked out within the project of the Czech Science Foundation No. 42-201060 "The Migratory Patterns of Immigrants (and Natives) in the Czech Republic: Concentration or Diffusion Processes? (with a focus on the analysis of influencing factors and integration processes)".

\section{References}

Act No. 435/2004 Coll., on Employment. (Czech legislation).

Act No. 326/1999 Coll., on the Stay of Foreigners on the territory of the Czech Republic. (Czech legislation).

Azarnert, L., V. (2012). Guest-worker Migration, Human Capital and Fertility. Review of Development Economics, 16(2), 318-330.

Bertoli, S., Moraga, J. F., Ortega, F. (2013). The determinants of International Migration Accounting for Self-selection. Retrieved March 10, 2013, from http://siteresources.worldbank.org/INTTRADERESEARCH/Resources/544824-1323963330969/83221971323963911280/Bertoli_Moraga_Ortega.pdf.

Blažek, J., Csank, P. (2007). A New Phase of Regional Development in the Czech Republic? Sociologický časopis, 43(5), 945-965. 
Blažek, J., Netrdová, P. (2009). Can development axes be identified by socio-economic variables? The case of Czechia. Geography, 114(4), 245-262.

Castles, S. (2002). Migration and Community Formation under Conditions of Globalization. International Migration Review, 36(4), 1143-1168.

Castles, S. (2006). Guestworkers in Europe: A resurrection? Internation Migration Review, 40(4), 741-766.

Cerna, L. (2010). Policies and practices of highly skilled migration in times of the economic crisis. International Migration Papers, 99, Geneva: ILO.

CNB (2013). Foreign direct investments. Retrieved February 18, 2013 from http://www.cnb.cz/cs/statistika/platebni_bilance_stat/publikace_pb/pzi/.

CSO (2012). Classification of occupations (CZ-ISCO). Retrieved December 30, 2012 from http://www.czso.cz/csu/klasifik.nsf/i/klasifikace_zamestnani_(cz_isco).

CSO (2013a). Districts by statistical classification. Retrieved March 3, 2013 from http://www.czso.cz/csu/rso.nsf/i/okres_NUTS.

CSO (2013b). Regional statistics. Retrieved March 15, 2013 from http://www.czso.cz/csu/2012edicniplan.nsf/p/1303-12.

Čermák, Z., Janská, E. (2011). Distribution and migration of foreigners as a part of the socio-geographical differentiation of Czechia. Geography, 116(4), 422-439.

Davis, T., Hart, D. M. (2010). International Cooperation to Manage High-Skill Migration: The Case of India-U.S. Relations. Review of Policy Research, 27(4), 509-526.

Docquier, F., Marfouk, A., Özden, C., Parsons, C. (2013). Geographic, Gender and Skill Structure of International Migration. Retrieved March 9, 2013. Available on:

http://perso.uclouvain.be/frederic.docquier/filePDF/DMOP-ERF.pdf.

Drbohlav, D. (1995). International Migration in the Czech Republic - Regional Aspects. In Faltan, L. (ed.). Regions-Self-Government-European Integration (Case of V-4 Countries) $\left(1^{\text {st }} \mathrm{ed}\right)$. Bratislava: Institute for Sociology of Slovak Academy of Science.

Drbohlav, D., Medová, L., Čermák, Z., Janská, E., Čermáková, D., Dzúrová, D. (2010). Migrace a (i)migranti v Česku. Kdo jsme, odkud přicházíme, kam jdeme? (1 $\left.1^{\text {st }} \mathrm{ed}\right)$. Praha: Sociologické nakladatelství (SLON).

Gächter, M., Schwazer, P., Theurl, E. (2012). Stronger Sex but Earlier Death: A MultiLevel Socioeconomic Analysis of Gender Differences in Mortality in Austria. DANUBE: Law and Economics Review, (1), 1-23.

Gibson, J., McKenzie, D. (2012). The economic consequences of "brain drain" of the best and brightest: microeconomic evidence from five countries. The Economic Journal, 122(560), 339-375.

Gross, D. M., Schmitt, N. (2012). Low- and High-Skilled Migration Flows: Free Mobility versus other Determinants. Applied Economics, 44(1), 1-20.

Gross, D. M., Schmitt, N. (2006). Why do low and high-skill workers migrate? Flow evidence from France. SECifo working paper, 1797, category 7: trade policy.

Hampl, M. (2001). Geografie transformace v České republice: celkové zhodnocení. In Hampl, M. (ed). Regionální vývoj: Specifika české transformace, evropská integrace a obecná teorie. Praha: DemoArt. 2001. 
Hampl, M. (2005). Geografická organizace společnosti v České republice: transformační procesy a jejich obecný kontext ( $\left.1^{\text {st }} \mathrm{ed}\right)$. Prague: DemoArt.

Hanson, G. (2013). International Migration and Development. Retrieved February 24, 2013 from http://siteresources.worldbank.org/EXTPREMNET/Resources/489960-

1338997241035/Growth_Commission_Workshops_Equity_Hanson_Paper.pdf.

Horvath, T. (2012). Immigration and the Distribution of Wages in Austria. DANUBE: Law and Economics Review, (3), 55-69.

Huber, P., Pfaffermayer, M., Wolfmayr, Y. (2011). Are There Border Effects in the EU Wage Function? DANUBE: Law and Economics Review, 2(2), 23-41.

Chaloff, J., Lemaitre, G. (2009). Managing Highly-Skilled Labour Migration: A Comparative Analysis of Migration Policies and Challenges in OECD Countries. OECD Social, Employment and Migration, Working Papers, 79. Paris: OECD Publishing.

ISPV (2013). Methodological center for CZ-ISCO. Retrieved January 30, 2013, from http://www.ispv.cz/cz/Metodicke-centrum-CZ-ISCO.aspx .

Jennissen, R. (2003). Economic Determinants of Net International Migration in Western Europe. European Journal of Population, 19(2), 171-198.

Jennissen, R. (2004). Macro-economic determinants of international migration in Europe. Dissertation thesis. Amsterdam: Dutch University Press.

Khoo, S.-E., Hugo, G., McDonald, P. (2010). Skilled Migration from Europe to Australia. Population, Space and Place, 17(5), 550-566.

Khoo, S.-E., McDonald, P., Voigt-Graf, C., Hugo, G. (2007). A Global Labor Market: Factors Motivating the Sponsorship and Temporary Migration of Skilled Workers to Australia. International Migration Review, 41(2), 480-510.

Koser, K., Salt, J. (1997). The Geography of Highly Skilled International Migration. International Journal of Population Geography, 3(4), 285-303.

Kostaki, A., Katzamanis, B., Stathakis, D. (2013). The spatial clustering of immigrant population in Greece. Retrieved March 9, 2013 from

http://ec.europa.eu/ewsi/en/resources/detail.cfm?ID_ITEMS=29982.

Kotlán, I., Machová, Z. (2012). World Tax Index: Methodology and Data. DANUBE: Law and Economics Review, 3(2), 19-33.

Lobodzinska, A. (2011). Immigrants and Immigration Policy in Ageing Finland. Bulletin of Geography, Socio-economic Series, 15, 43-55.

Massey, D. S., Arrango, J., Graeme, H., Kouaouci, A., Pellegrino, A., Taylor, K. E. (1993). Theories of International Migration: A Review and Appraisal. Population and Development Review, 19(3), 431-466.

Massey, D. S., Arrango, J., Graeme, H., Kouaouci, A., Pellegrino, A., Taylor, K. E. (1998). Worlds in Motion: Understanding International Migration at the End of the Millennium $\left(1^{\text {st }}\right.$ ed). Oxford: Oxford University Press.

Mayda, A. M. (2007). International migration: A panel data analysis of the determinants of bilateral flows. London: University College London, Centre for Research and Analysis of Migration, 33.

Mayda, A. M. (2010). International migration: A panel data analysis of the determinants of bilateral flows. Journal of Population Economics, 23(4), 1249-1274. 
Melegh, A., Kondratieva, E., Salmenhaare, P., Forsander, A., Hablicsek, L., Hegyesi. A. (2004). Globalisation, Ethnicity and Migration. The comparison of Finland, Hungary and Russia. Working papers on population, family and welfare, 79. Budapest: Central Statistical Office.

MLSA (2012). Internal statistics of the number of renewed work permits and foreign employees registered with the labour office.

Nosek, V. (2010). Prostorové aspekty sociálních nerovnoměrností: Česko v kontextu střední a východní Evropy. Dissertation thesis. Prague: Faculty of Science, Charles University in Prague.

Novotný, J., Janská, E., Čermáková, D. (2007). Spatial distribution of immigrants in Czechia and its influencing factors: an attempt at quantitative analysis. Geography, 112(2), 204-220.

Portes, A., Böröcz, J. (1989). Contemporary Immigration: Theoretical Perspectives On Its Determinants and Modes Of Incorporation. International Migration Review, 23(3), 606-630.

Rovolis, A., Tragaki, A. (2012). The Regional Dimension of Migration in Greece: Spatial Patterns and Causal Factors. Retrieved July 1, 2012, from www: http://www-sre.wuwien.ac.at/ersa/ersaconfs/ersa05/papers/774.pdf.

Salt, J. (1984). High Level Manpower Movements in Northwest Europe and the Role of Careers: An Ecplanatory Framework. International Migration Review, 17(4), 633-652.

Salt, J. (1992). The future of International Labor Migration. International Migration Review, 26(4), 1077-1111.

Semyonov, M., Gorodzeisky, A. (2005). Labor Migration, Remittances and Household Income: A Comparison between Filipino and Filipina Overseas Workers. International Migration Review, 39(1), 45-68.

Schovánková, S. (2013a). How many non-EU foreigners are in fact employed in the Czech Republic? The case of Ukrainians, Vietnamese and Mongolian workers. Demografie, in print.

Schovánková, S. (2013b). Governance of the international migration of highly-skilled professionals: an empirical analysis from the Czech Republic. Politics in Central Europe, 9(1), in print.

Schovánková, S., Drbohlav, D. (2013). Spatial distribution of a foreigner labour force by regions of Czechia during the global economic crisis. Ekonomický časopis, in print.

Spurná, P. (2008). Spatial Autocorrelation - A Pervasive Phenomenon in the Analysis of Spatial Data?. Sociologický časopis, 44(4), 767-787.

Štika, R. (2002). Indices of the horizontal and vertical geographical positions. Charles University in Prague, Department of the social geography and regional development.

Tóth, G., Kinces, Á. (2010). Regional distribution of immigrants in Hungary. Hungarian Geographical Bulletin, 59(2), 107-130.

Willis, K. (1975). Regression models of migration. An economic reappraisal of some techniques. Geografiska Annaler, 57 B (1), 42-54.

Van Der Gaag, N., Van Wissen, L. (2001). Determinants of the subnational distribution of immigration. Tijdschrift Economische en Sociale Geografie, 92(1), 27-41. 
Van Der Gaag, N., Van Wissen, L. (2002). Modelling Regional Immigration: Using Stocks to Predict Flows. European Journal of Population, 18(4), 387-409.

Venturini, A., Villosio, C. (2012). Labour market assimilation of foreign workers in Italy. Oxford Review of Economic Policy, 24(3), 518-542.

Wermuth, D., Wermuth, N. (1975). Some determinants of the migration of professional manpower. Demography, 12(4), 615-628. 